\title{
Vegetation analyses of Sebangau peat swamp forest, Central Kalimantan
}

\author{
EDI MIRMANTO \\ Botany Division, Research Centre for Biology, Indonesian Institute of Sciences (LIPI), Jl. Raya Bogor-Jakarta km 46, Cibinong-Bogor 16911, West Java, \\ Indonesia, Tel.: +62-21-8765066/7, Fax.: +62-21-8765063, email: emirmanto@ yahoo.co.id
}

Manuscript received: 24 June 2009. Revision accepted: 16 September 2009.

\begin{abstract}
Mirmanto E (2010) Vegetation analyses of Sebangau peat swamp forest, Central Kalimantan. Biodiversitas 11: 82-88. The vegetation analysis study has been made in Sebangau peat-swamp forest, Central Kalimantan. Eight permanent plots of 50-m x 50-m were set-up distribute from close to the river with shallow peat-layer up to the inland with relatively deep peat-layer. Enumeration of trees (GBH > $15 \mathrm{~cm}$ ) was conducted in all of 8 plots. Overall there are 133 species (taxa) were recorded within 8 plots belong to 34 families where Dipterocarpaceae, Clusiaceae, Myrtaceae and Sapotaceae were the most dominant family. Out of all species recorded, Combretocarpus rotundatus, Palaquium leiocarpum, Stemonurus scorpioides and Tristania whittiana were the most dominant species. Two community's types namely Combretocarpus rotundatus-Shorea balangeran community and Palaquium leiocarpum-Eugenia densinervium community were recognized and they distributed in slightly different habitat condition. The sequence of these two communities' shows significantly related to both distances to river and peat-depth. In addition there was indication the presence of habitat preference among tree species.
\end{abstract}

Key words: vegetation, peat-swamp, community, Sebangau, Central Kalimantan.

\section{INTRODUCTION}

The peat-swamp forests dominate in Central Kalimantan characterized by poor nutritional conditions. This is a unique and important ecosystem, but they fragile and sensitive for development. Indonesia covered by a large area of peat-swamp and heath forests, which mainly distributed in Sumatra, Kalimantan and Irian Jaya. So far, the data and information of their occurrence, range and total area are still not properly known.

In fact the wetland forests (peat-swamp and heath forest) in Malesia region have been studied for more than three decades (Anderson 1961; 1963; 1964; 1972; 1983; Sambas et al. 1994; Sambas and Suhardjono 1994; Ibrahim 1997; Saribi and Riswan 1997; Shepherd et al. 1997; Siregar and Sambas 1999; Mansur 1999; Page et al. 1999; Suzuki et al., 1999; Yusuf 1999; Purwaningsih and Yusuf 2000). However, the knowledge of the peat-swamp forest especially for their biodiversity, ecological function and dynamics of this forest is still limited. Most of those previous studies reported on the floristic composition and the structure, and there was big variation among study sites. This may indicate that local environment condition play an important role in development of vegetation. Some previous studies such as Brady (1997), Shepherd et al. (1997), Stoneman (1997), and Page et al. (1999), in general reported the presence of relationship between vegetation type and peat-depth, and sequence of vegetation type from the river to the inland. However little is known about the relationship between vegetation type and distance to river and peat-depth.

Aim of this study is to understand, the structure, floristic composition and communities patterns of
Sebangau peat swamp forest, and their relation to the habitat conditions. For that reason, long term ecological studies have been made by established some permanent plots on some different habitat condition sites. The present report is a part result of those long-term studies, which concern to the vegetation analyses, based on data collected from eight permanent plots.

\section{MATERIAL AND METHODS}

\section{Study site}

The study has been made in the Sebangau peat-swamp forest, situated at $2^{\circ} 18$ ' 24 " S S and $113^{\circ} 55^{\prime} 4.1^{\prime \prime} \mathrm{E}$, at about $10 \mathrm{~m}$ above sea level. The study area is belong to Kereng Bangkirai village about 20-km southwest of Palangka Raya, Central Kalimantan. The vegetation here is characteristic of peat-swamp forest, with condition in general was flooded and with the peat layer depth varied from 2 to $10 \mathrm{~m}$ up. In general the sites relatively undisturbed forest, except for some places was damage due to the selective logging with varied in forest disturbance depending on the intensity of logging. According to Schmidt and Ferguson (1957) classification, the climates in those three study areas are belonging to type of $\mathrm{A}$, with mean annual rainfall of about $2400 \mathrm{~mm}$. The mean daily temperature varied from $25^{\circ}$ up to $33^{\circ} \mathrm{C}$, with high in humidity (up to $90 \%$ ).

\section{Field survey}

Eight plots of $50-\mathrm{m} \times 50-\mathrm{m}$ were established on a relatively undisturbed forest which is distributed along the trail from about $1 \mathrm{~km}$ from the river to the inland, with peat 
layer depth varied from 0.6 to $5 \mathrm{~m}$. The distance between plots was about $500 \mathrm{~m}$ to $1000 \mathrm{~m}$; depend on the physiognomic change of the vegetation. Within each plot the tentative species name, girth at $1.3 \mathrm{~m}$ above the ground $(\mathrm{GBH})$ and the position of each individual were recorded for the trees with $\mathrm{GBH}>15 \mathrm{~cm}$. The voucher specimens of each tentative species name were collected for further identification.

\section{Data analyses}

The vegetation data were analysis by multivariate analysis (MVSP version 3-1, Kovach Computing Service, UK) and multiple regression analysis (Statistica version 5, Stat soft, CA). Shannon's diversity index method was used to calculate the species diversity of each plot and in addition the Tanjung Puting and Barito Ulu data (Mirmanto, unpublished data) was also including in calculation for comparison. The principal component analysis (PCA) was used in order to determine the distribution among 8 plots based on the BA. Multiple regression analysis was used to examine the relation between 2 principal component (axes) and environmental factors (peat-depth and distance to river), species richness (number of species and diversity index) and biomass (density and basal area) as independent variables. The multiple regression analysis was also used to predict the variant of PCA-score of uncommon species. Forty-eight species, which distributed in at least in 3 plots was selected for this analysis. Four factors were mean peat-depth; mean distance to river; standard deviation of peat-depth and standard deviation of distance to river were used in this analysis. The mean and standard deviation of peatdepth and distance to river were calculated from the data of peat-depth and distance to river of each plot. Based on the environment data (distance to river and peat-depth) of each plot, we classify the study area into to 3 class of peat-depth (shallow $<2 \mathrm{~m}$, medium $2-3$ $\mathrm{m}$ and deep $>3 \mathrm{~m}$ ), and 3 class of distance to river (close $<2 \mathrm{~km}$, medium 2-3 $\mathrm{km}$ and far $>3 \mathrm{~km}$ ). The habitat preference of each species to each habitat type was tested using Kolmogorov-Smirnov's (K-S) test and goodness fit test for continuous data.

\section{RESULTS AND DISCUSSION}

\section{Floristic and forest structure}

Out of all trees $(\mathrm{GBH}>15 \mathrm{~cm})$ recorded in the 8 plots, there were 103 taxa belonged to 51 families. There were variations in species composition among the plots, and only 7 species of all species recorded were distributed in more than 6 plots and more then 30 species were observed in only 1 plot. Gymnacranthera eugeniifolia was the most frequent species (distributed in 8 plots), followed by Horsfieldia crassifolia, Stemonurus scorpioides, Nephelium maingayi and Tristania whittiana (distributed in 7 plots respectively). The species-area curves for 8 plots and Barito Ulu and Tanjung Puting plots as comparison shown in Figure 1.

The most three dominant family were Clusiaceae, Sapotaceae and Myrtaceae, which occupies almost $50 \%$ of the total basal area (Table 1). However there were some variation between plots with the Sapotaceae, Rhizophoraceae, Dipterocarpaceae and Polygalaceae each leading in the basal area at some plots. Palaquium leiocarpum was the most dominant species with basal area of $6.5 \mathrm{~m}^{2} /$ ha or about $12 \%$ of total basal area, followed by, Combretocarpus rotundatus, Eugenia castaneum, and Eugenia densinervium (Table 2). Those first three species were also recorded as common species in several peat-swamp forest study sites but not always become abundant species. On the other hand, Shorea balangeran and Xanthophyllum eurhynchum apparently were only distributed in a specific habitat. In Table 3, the Shannon's diversity index in all the 8 plots was lower then in lowland mixed dipterocarp forest in Barito Ulu, but comparable to Tanjung Putting. The mean tree density was $2689 \mathrm{ha}^{-1}$ (range 1660-3064) and the mean tree basal area was 31.5-m2 ha- (range 20.4-44.6). Only $0.14 \%$ of trees with a dbh $>50 \mathrm{~cm}$ (Figure 2) and the biggest tree was Combretocarpus rotundatus reach up to $95.5 \mathrm{~cm}$ in $\mathrm{dbh}$.

Table 1. Total basal area $\left(\mathrm{m}^{2} / \mathrm{ha}\right)$ of some dominant families recorded in the study area.

\begin{tabular}{lcccccccccc}
\hline Family & S7 & S8 & S1 & S2 & S3 & S4 & S5 & S6 & $\left.\mathbf{( m}^{2} / \mathbf{h a}\right)$ & $\mathbf{( \% )}$ \\
\hline Clusiaceae & 0.50 & 0.80 & 0.80 & 0.90 & 1.10 & 1.00 & 1.30 & 1.60 & 8.00 & 14.04 \\
Sapotaceae & & & 0.40 & 0.90 & 1.80 & 2.40 & 2.00 & 0.50 & 8.00 & 14.04 \\
Myrtaceae & 0.60 & 1.00 & 1.00 & 0.70 & 1.20 & 1.00 & 0.80 & 1.60 & 7.90 & 13.86 \\
Rhizophoraceae & 0.80 & & 1.00 & & 0.30 & 0.20 & & 1.80 & 5.90 & 10.35 \\
Dipterocarpaceae & 0.50 & 0.70 & 0.10 & 0.50 & 0.30 & 0.30 & 0.60 & 0.40 & 3.40 & 5.96 \\
Polygalaceae & 1.00 & 0.60 & 0.30 & 0.40 & 0.30 & 0.30 & 0.10 & 0.20 & 3.20 & 5.61 \\
Euphorbiaceae & & & 0.50 & 0.50 & 0.50 & 0.30 & 0.80 & 0.30 & 2.90 & 5.09 \\
Others (27) & 1.60 & 2.00 & 1.60 & 2.80 & 2.20 & 2.90 & 2.70 & 1.90 & 17.70 & 31.05 \\
\hline
\end{tabular}

Table 2. Total basal area $\left(\mathrm{m}^{2} / \mathrm{ha}\right)$ of some dominant species recorded in the study area.

\begin{tabular}{llllllllllll}
\hline Species & S7 & S8 & S1 & S6 & S2 & $\mathbf{S 3}$ & $\mathbf{S 4}$ & $\mathbf{S 5}$ & $\mathbf{( \mathbf { m } ^ { 2 } / \mathbf { h a } )}$ & $\mathbf{( \% )}$ \\
\hline Palaquium leiocarpum & & & & & 0.4 & 0.6 & 1.5 & 2.1 & 1.9 & 6.5 & 11.7 \\
Combretocarpus rotundatus & 0.8 & 1.8 & 1.0 & 1.8 & & 0.3 & 0.2 & & 3.3 & 5.9 \\
Eugenia densinervium & & 0.3 & 0.5 & 0.8 & 0.3 & 0.6 & 0.5 & 0.5 & 3.2 & 5.8 \\
Eugenia castaneum & 0.1 & 0.2 & 0.3 & 0.6 & 0.2 & 0.4 & 0.4 & 0.2 & 2.1 & 3.8 \\
Calophyllum teysmannii & 0.1 & 0.3 & 0.2 & 0.1 & 0.1 & 0.7 & 0.4 & 0.1 & 1.6 & 2.9 \\
Xanthophyllum palembanicum & 0.1 & 0.3 & 0.2 & 0.2 & 0.4 & 0.3 & 0.1 & 0.1 & 1.3 & 2.3 \\
Calophyllum biflorum & 0.1 & & & 1.0 & & & & 0.6 & 1.6 & 2.9 \\
Gonystylus bancanus & & 0.2 & 0.5 & 0.1 & 0.4 & 0.1 & 0.1 & 0.2 & 1.4 & 2.5 \\
Neoscortechinia philippinensis & & & 0.3 & 0.2 & 0.3 & 0.2 & 0.2 & 0.4 & 1.6 & 2.9 \\
Xanthophyllum eurhynchum & 0.9 & 0.3 & & & & & 0.2 & & 0.2 & 0.4 \\
Calophyllum inophyllum & & & 0.2 & & 0.6 & 0.1 & 0.4 & & 1.3 & 2.3 \\
Acronychia porteri & & & 0.2 & & 0.1 & 0.1 & 0.1 & 0.7 & 1.2 & 2.2 \\
Horsfieldia crassifolia & & 0.1 & 0.1 & 0.1 & 0.3 & 0.3 & 0.2 & 0.1 & 1.1 & 2.0 \\
Blumeodendron elateriospermum & & & 0.2 & 0.1 & 0.2 & 0.3 & 0.1 & 0.3 & 1.2 & 2.2 \\
Shorea guiso & & & & 0.2 & 0.3 & 0.2 & 0.3 & 0.2 & 1.2 & 2.2 \\
Other species (88) & 2.9 & 3.4 & 1.8 & 2.6 & 2.9 & 2.1 & 2.7 & 2.7 & 21.1 & 38.0 \\
\hline
\end{tabular}




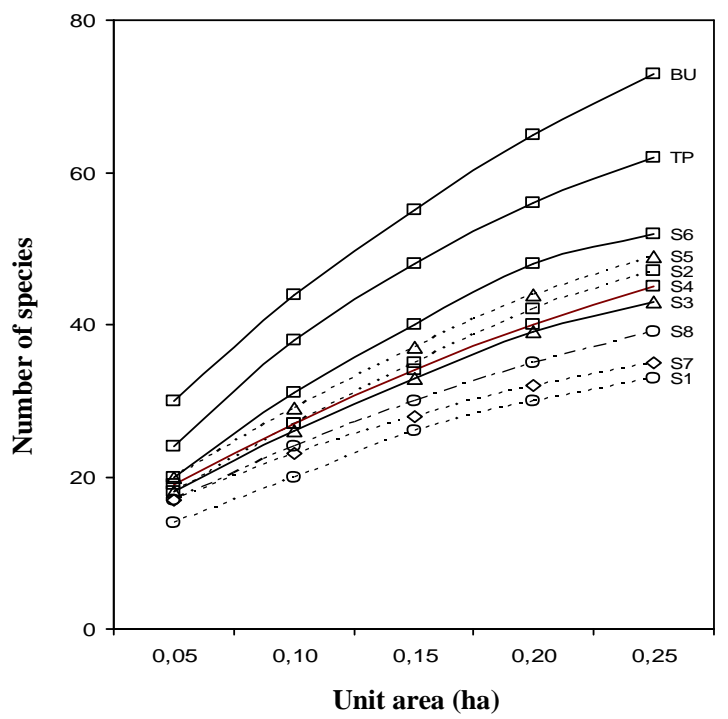

Figure 1. Species-area curve of 8 plot in Sebangau $(\mathrm{S} 1, \ldots, \mathrm{S} 8)$, Barito Ulu (BU) Tanjung Puting (TP).

Table 3. Number of species (NS), density ( $D=$ trees/ha), basal area $(\mathrm{BA}=\mathrm{m} 2 / \mathrm{ha})$ and Shanon Indek Diversity (SDI) of 8 plots in Sebanagu, Barito Ulu and Tanjung Puting

\begin{tabular}{lcccccc}
\hline \multicolumn{1}{c}{ Study sites } & $\begin{array}{c}\text { Area } \\
\text { (ha) }\end{array}$ & $\begin{array}{c}\text { Forest } \\
\text { type }\end{array}$ & NS & D & BA & SDI \\
\hline Barito Ulu & 0.25 & MDF & 73 & 720 & 32.60 & 1.90 \\
Tanjung Puting & 0.25 & PSF & 62 & 1660 & 44.60 & 1.64 \\
Sebangau-1 & 0.25 & PSF & 33 & 2160 & 22.80 & 1.68 \\
Sebangau-2 & 0.25 & PSF & 47 & 2876 & 26.80 & 1.66 \\
Sebangau-3 & 0.25 & PSF & 45 & 3172 & 30.80 & 1.58 \\
Sebangau-4 & 0.25 & PSF & 46 & 3740 & 33.60 & 1.50 \\
Sebangau-5 & 0.25 & PSF & 47 & 3680 & 33.20 & 1.47 \\
Sebangau-6 & 0.25 & PSF & 48 & 3136 & 33.20 & 1.59 \\
Sebangau-7 & 0.25 & PSF & 35 & 2940 & 20.00 & 1.53 \\
Sebangau-8 & 0.25 & PSF & 39 & 3064 & 20.40 & 1.62 \\
\hline Notes: MDF=mixed dipterocarp forest: PSF= peat swamp forest
\end{tabular}

Notes: $\mathrm{MDF}=$ mixed dipterocarp forest; $\mathrm{PSF}=$ peat swamp forest

\section{Ordination}

The contribution rate of the first principal component PCA (Axis-1) was 55.4\%, and the second (Axis-2) was $10.5 \%$. Thus the first two axes explained $65.9 \%$ of variation. Therefore, we investigated the vegetation patterns by the two axes. Figure 3 shows the distributions of plots along the two axes, which tended to correspond to both gradient of distance to river and peat-depth.

The results of multiple regression analysis suggested that the Axis-1 was strongly correlated with distance to river, tree density and basal area whereas Axis-2 was more related to peat-depth (Table 4). In addition, positive correlation $(\mathrm{R}=0.67)$ between distance to river and peatdepth, indicated that the peat-depth increased with increasing distance to river. On the other hand species richness (number of species and diversity index) was not significantly correlated to both Axis-1 and Axis-2.

The multiple regressions of selected species provided the results that Axis-1 was significantly related with peatdepth, and Axis-2 was correlated with distance to river (Table 5). These results mean the existence of those species influenced by both peat-depth and distance to river.

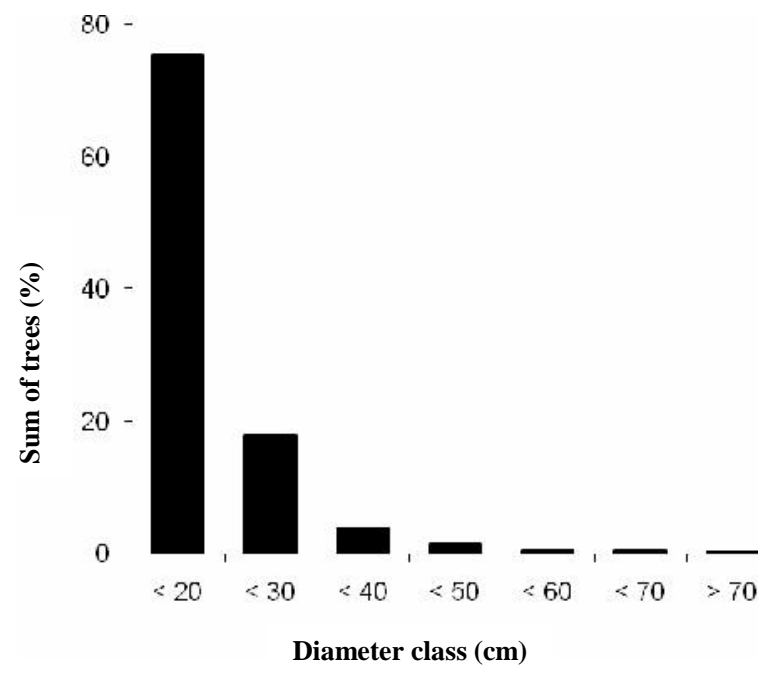

Figure 2. Diameter class distribution of trees recorded within 8 plots in the study area.

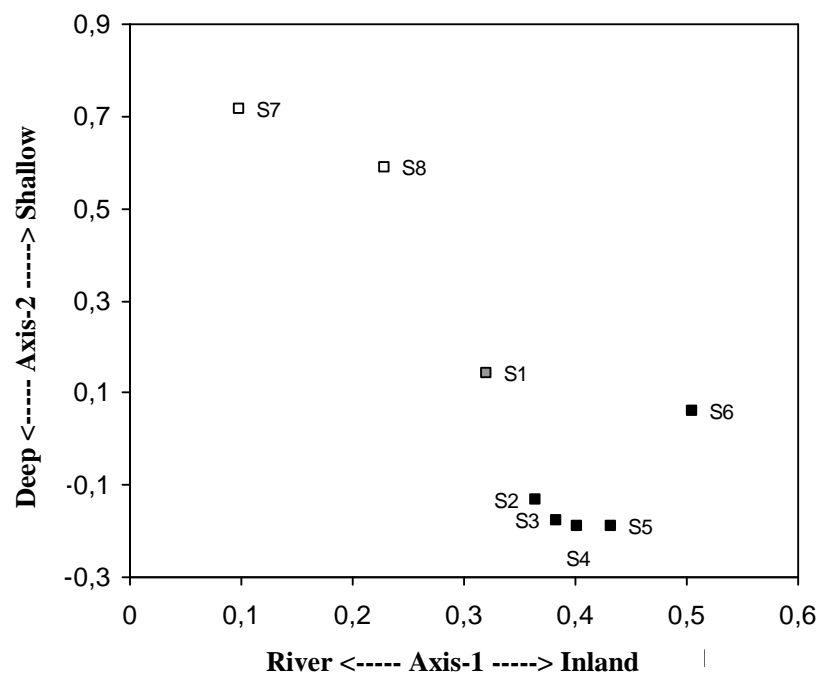

Figure 3. PCA loadings of 8 plots on the coordinates of PC axes 1 and 2 in Sebangau peat-swamp forest

Table 4. Standardized coefficients of multiple regression value in order to determining variant of PCA score of 8 plots using two environmental factors (peat-depth and distance to river) and four parameters (density, basal area, number of species and diversity index)

\begin{tabular}{l|ll}
\hline \multicolumn{1}{c}{ Independent variable } & \multicolumn{2}{c}{ Dependent variable } \\
\cline { 2 - 3 } & \multicolumn{1}{c}{ Axis-1 } & Axis-2 \\
\hline Peat-depth $(\mathrm{m})$ & $0.534^{*}$ & $0.714^{* *}$ \\
Distance to river $(\mathrm{km})$ & $0.896^{* * *}$ & $0.623^{*}$ \\
Density (tree/0.25 ha) & $0.947^{* * *}$ & $0.635^{*}$ \\
Basal area $\left(\mathrm{m}^{2} / 0.25 \mathrm{ha}\right)$ & $0.884 * * *$ & 0.477 \\
Number of species & 0.333 & 0.251 \\
Shanon Index Diversity & 0.242 & 0.368 \\
F & $16.374 * * *$ & $6.12^{* *}$ \\
\hline
\end{tabular}

Note: $\mathrm{P} *<0.05 ; * * \mathrm{P}<0.01 ; * * * \mathrm{P}<0.001$ 
Table 5. Standardized coefficients of multiple regression value in order to determining variant of PCA score of some dominant species using four environmental factors.

\begin{tabular}{lll}
\hline \multicolumn{1}{c}{ Independent variable } & \multicolumn{2}{c}{$\begin{array}{c}\text { Dependent variable } \\
\text { Axis-1 }\end{array}$} \\
& \multicolumn{1}{c}{ Axis-2 } \\
\hline Mean of peat-depth $(\mathrm{m})$ & $0.387^{* * *}$ & $0.241^{*}$ \\
Standard deviation of peat-depth & $0.326^{* *}$ & 0.113 \\
Mean distance to river $(\mathrm{km})$ & 0.246 & $0.429^{*}$ \\
Standard deviation of distance to river & 0.097 & $0.317^{* * *}$ \\
$\mathrm{~F}$ & $17.86^{* * *}$ & $24.38^{* * *}$ \\
\hline
\end{tabular}

Note: $\mathrm{P} *<0.05 ; * * \mathrm{P}<0.01 ; * * * \mathrm{P}<0.001$

Out of all selected species, almost all species showed significant habitat preference to both peat-depth and distance to river class, except for 1 species was not significant for peat-depth class and 3 species was not significant for distance to river classes (Table 6). This indicates that the distribution of species in general affected by those two environmental factors. However there are any differences in species associated to habitat preferences.

The Figure 4 illustrated the distribution of some dominant species along the two axes of PCA. In general there were two main groups can be differentiated. The first group is consists of species, which distributed on shallow to medium peat-layer and close to medium distance to river; while the second group consists of species on medium to deep peat-layer and medium to far distance to river.

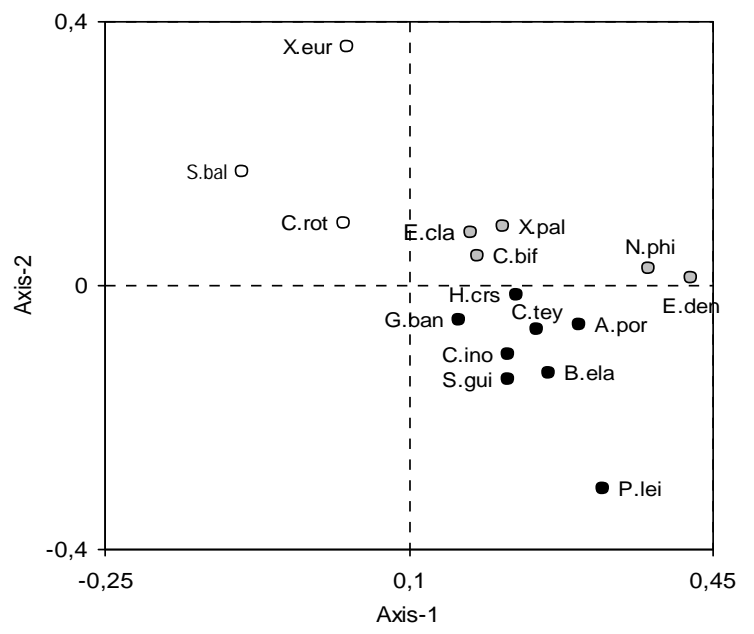

Figure 4. Distribution of some selected species two PCA Axis. X.eur = Xanthophyllum eurhynchum, S.bal = Shorea balangeran, C.rot $=$ Combretocarpus rotundatus; E.cla $=$ Eugenia clavatum, C.bif $=$ Calophyllum biflorum, N.phi $=$ Neoscortechinia philippinensis, H.crs = Horsfieldia crassifolia, E.den = Eugenia densinervium, G.ban $=$ Gonystylus bancanus, A.por $=$ Acronychia porteri, C.tey $=$ Calophyllum teysmannii, C.ino $=$ Calophyllum inophyllum, S.gui = Shorea guiso, B.ela = Blumeodendron elateriospermum, P.lei = Palaquium leiocarpum.

The results show that species diversity in the study area was relatively similar to others study in peat swamp forest in Kalimantan (Table 7), but it was still lower compared to lowland mixed-dipterocarp forest at Barito Ulu (Table 2, Figure 1). Out of 133 species recorded, almost dominant species were representing characteristic of peat-swamp (cf. Anderson 1961; 1963: Simbolon and Mirmanto 2000). However there were non-indigenous species of peat-swamp recorded within some plots. The presence of nonindigenous species indicated that there was any changing in environmental condition, that to open possibility for species from out-side were able to grow and develop there.

Non-indigenous species such as Macaranga caladiifolia, Macaranga spp., and Glochidion littorale were recorded within and around the shallow-peat close to river plots. Those species recognize as secondary species, which usually adaptable to various conditions such as open and disturbed forests. In addition the Glochidion littorale was also recorded as a component of the riverside disturbed mangrove forest community (Mirmanto et al. 1989), and expected as sea-dispersed species. So the occurrence of this non-indigenous species in the study area may be able to be considered as the consequence of environment change and flooding.

The flooding is one factor to damage vegetation, but it depends on the frequency of flood and nature of vegetation. The period of flooding is one importance factors to stimulate habitat segregation in riparian forest (Robertson et al. 1978), which result in several of vegetation type (Inoue and Nakagoshi 2000). The presence of floodtolerance species resulted in differences species composition from riverside to the inland (Oliver and Larson 1990). In this study, as indicated by multiple regression analysis (Table 4), show that there were significant effect of both distance to river and peat-depth to distribution of vegetation patterns.

Distance to river may to explain incidence of flood, with assumption that flooding usually more frequent in closer to river area. By this assumption there were at least three kind of vegetation in relation to incidence of flooding were recognized, i.e. vegetation on the frequent flood area, on infrequent flood area and on seasonally flood area. There were significantly different in floristic composition between vegetation on frequent flood area to others (ANOVA, p <0.01). Studies in flood-plain forest reported that flooding reduce the species richness (Yanoski 1982; Hupp 1992) because swept away source of recruitments. Other study (Robertson et al. 1978) however, reported that flooding is as stimulator to create the new habitat type. That means the various habitat types will be built up on the areas where the most frequent of flood occur. Consequence the most frequent flood areas should be more heterogeneous in species composition.

In this study, while there was no significantly correlated between distance to river and species richness (Table 4), but indicated that species richness (expressed by diversity index) was lower in close to river plots. On the other hand, there was significant correlation between biomass (expressed by density and basal area) and distance to river. Some studies in laboratory scale (Jackson 1979; Tang and Kozlowski 1982; Save and Serrano 1986; Hurng et al. 1994; Ismail and Noor 1996) reported that for species level 
Table 6. Habitat classification based on species preference for peat-depth and distance to river in the study area.

\begin{tabular}{|c|c|c|c|c|c|}
\hline \multirow[b]{2}{*}{ Species } & \multirow[b]{2}{*}{$\mathbf{n}$} & \multicolumn{2}{|c|}{ Peat-depth } & \multicolumn{2}{|c|}{ Distance to river } \\
\hline & & KS-d ${ }^{+}$ & $\begin{array}{c}\text { Habitat } \\
\text { classes }^{++}\end{array}$ & KS-d & $\begin{array}{c}\text { Habitat } \\
\text { classes }\end{array}$ \\
\hline Combretocarpus rotundatus & & $0.273 * *$ & MP & $0.261^{*}$ & $\mathrm{MD}$ \\
\hline Tetramerista glabra & & $0.238 * *$ & MP & 0.154 & $\mathrm{~F}$ \\
\hline Shorea balangeran & & $0.273 * *$ & $\mathrm{~S}$ & $0.349 * * *$ & MD \\
\hline Diospyros dajakensis & 100 & $0.235 * *$ & $\mathrm{D}$ & $0.242 * * *$ & $\mathrm{~F}$ \\
\hline Horsfieldia crassifolia & 158 & $0.191 * *$ & MP & $0.219 * * *$ & $\mathrm{~F}$ \\
\hline Lithocarpus elegans & & $0.217 *$ & MP & $0.239 * * *$ & $\mathrm{~F}$ \\
\hline Ternstroemia magnifica & & 0.117 & MP & $0.224 * *$ & $\mathrm{~F}$ \\
\hline Cratoxylum glaucum & 157 & $0.259 * * *$ & MP & $0.186 * *$ & $\mathrm{~F}$ \\
\hline Stemonurus scorpioides & 196 & $0.352 * * *$ & MP & $0.194 * *$ & MD \\
\hline Gymnacranthera eugeniifolia & 157 & $0.294 * * *$ & MP & $0.182 * * *$ & $\mathrm{~F}$ \\
\hline Xanthophyllum palembanicum & 129 & $0.265 * * *$ & MP & $0.257 * * *$ & $\mathrm{~F}$ \\
\hline Campnosperma coriaceum & & $0.291 * * *$ & MP & $0.367 * * *$ & MD \\
\hline Syzygium clavatum & 115 & $0.269 * * *$ & MP & $0.277 * * *$ & MD \\
\hline Blumeodendron elateriospermum & 161 & $0.259 * * *$ & MP & $0.205 * * *$ & $\mathrm{~F}$ \\
\hline Calophyllum teysmannii & 143 & $0.239 * * *$ & MP & $0.211 * * *$ & $\mathrm{~F}$ \\
\hline Garcinia lateriflora & & $0.258 * * *$ & MP & $0.333 * * *$ & $\mathrm{~F}$ \\
\hline Acronychia porteri & 205 & $0.366 * * *$ & $\mathrm{D}$ & 0.148 & $\mathrm{~F}$ \\
\hline Lithocarpus leptogyne & & $0.369 * * *$ & $\mathrm{D}$ & $0.316 * * *$ & $\mathrm{~F}$ \\
\hline Sandoricum emarginatum & 104 & $0.264 * * *$ & $\mathrm{D}$ & $0.228 * * *$ & $\mathrm{~F}$ \\
\hline Gonystyllus bancanus & & $0.272 *$ & $\mathrm{~S}$ & 0.159 & MD \\
\hline Nephelium maingayi & & $0.325 * * *$ & $\mathrm{~S}$ & $0.249 * *$ & $\mathrm{C}$ \\
\hline Xanthophyllum eurhyncum & 206 & $0.258 * * *$ & $\mathrm{~S}$ & $0.266 * * *$ & $\mathrm{C}$ \\
\hline
\end{tabular}

Notes: +) The maximum difference between the value of observed and expected relative frequencies. Significance was tested by Kolmogorov-Smirnov goodness of fit test for continuous data. ++) Abbreviations of habitat class as follow: D: deep peat-depth; MP: medium peat-depth; S: shallow peat-depth; C: close to river; MD: medium distance to river; F: far from river.

Table 7. Number of species (NS), density (D), basal area $\left(B A=m^{2} / h a\right)$ of Sebangau plots and some other studies sites. *) $\mathrm{PSF}=$ peat swamp forest; $\mathrm{SPSF}=$ shallow peat swamp forest; $\mathrm{HF}=$ heath forest; DPSF= deep peat swamp forest).

\begin{tabular}{lrrrrl}
\hline \multicolumn{1}{c}{ Locality Site } & $\begin{array}{c}\text { Plot } \\
\text { (ha) }\end{array}$ & NS & \multicolumn{1}{c}{ D } & BA & \multicolumn{1}{c}{ Authors } \\
\hline Lahei (PSF*) & 0.25 & 47 & 1612 & 45.40 & This study \\
Sebangau (comb. of 4 SPSF*) & 1.00 & 86 & 2783 & 12.58 & This study \\
Tanjung Puting (SPSF*) & 0.25 & 87 & 1660 & 44.60 & This study \\
Lahei (comb. of 2 HF*) & 0.50 & 104 & 2290 & 30.75 & This study \\
Sebangau (comb. of 6 DPSF*) & 1.50 & 130 & 3110 & 31.55 & This study \\
Gunung Palung (PSF*) & 1.00 & 122 & 433 & 28.03 & Sudarmanto 1994 \\
Mensemat (PSF*) & 1.05 & 86 & 698 & 24.29 & Siregar et al. 1999 \\
Nyaru Menteng (PSF*) & 0.50 & 64 & 1004 & 52.40 & Saribi and Riswan 1997 \\
Ketapang (PSF*) & 1.00 & 61 & 513 & 17.67 & Sambas et al. 1994 \\
Ketapang (PSF*) & 0.20 & 42 & 535 & 14.27 & Sambas and Suhardjono 1994 \\
Tanjung Puting (PSF*) & 0.75 & 108 & 812 & 40.03 & Hamidi 1991 \\
\hline
\end{tabular}

flooding decrease the primary biomass productivity. This is probably physiologically of mechanism and processes in plant-tissue was not working properly under water stress condition. In fact the basal area and density in the study area was also lower in closer to river plots than in the inland. However, there was no significant effect of flooding on physiological processes for some dominant species of peat-swamp forest in Sebangau area (Naiola 1999).
In addition, there was not too strong in correlation between basal area and distance to river (R: 0.67). This indicates that any other factors such as peat-depth, geography, micro-topography and perhaps disturbance also involve influencing this phenomenon. However previous study (Suzuki et al. 1999) reported that there is close similarity between two geographically different sites. Therefore, combination geographic and habitat factor may be better to explain the effects of geography. In the study area the effects of geographic was clear as expressed in cluster analysis (Mirmanto, unpublished data). On the other hand, the SC community it was exactly different to other community, but there was slight difference in species composition among plots in this community. Graniero and Price (1999) reported that topography play a relatively small role in constructing forest community, but topography complexity increase species richness. Studies in mixeddipterocarp forest (Baillie et al. 1987) and neotropical lowland forest (Becker and Rabenold 1988) stated that microtopograhic variation have an effect on water availability and aeration status of soil. So, the microtopographic factor perhaps is more efficient to any studies in a relatively small-scale area.

Multiple regression analysis for some selected species explained the significant effects of peat-depth were stronger than distance to river (Table 5). The species-habitat preference test show that almost (94\%) all species were consistent significant to class of peat-depth (Table 7). This is similar results to those reported by Newberry and Proctor (1984) and Miyamoto et al. (2003) for heath forests, that edaphically (soil) factor play importance role in distribution of species. The influence of other variables such as micro-topographic and geographic on distribution of vegetation patterns is not too small to be ignored. Indeed among vegetation on the same class of peat-depth and/or 
distance to river but geographically different were dissimilar in floristic composition.

The availability of nutrient and efficiency of nutrient cycling is important factor in the distribution of forest community (Page et al. 1999). Consequently, the riverside vegetation that should be receiving more nutrients from the river flow, and the growth will be faster than inland vegetation. In addition the nutrient cycling efficiency in peat-swamp forest is relatively higher among poor nutrient soil study sites (Mirmanto 1999). The results however show that the basal area and density of closer to river community were lower than other community. A comparative study on nutrient cycling along gradient both peat-depth and distance to river is a good topic in order to explain the existence of peat swamp forest.

\section{CONCLUSIONS}

The species diversity in the study area was lower compared to lowland mixed-dipterocarp forest at Barito Ulu, but it was similar to some other Kalimantan peat swamp forest studies. Almost dominant species, such as Combretocarpus rotundatus, Palaquium leiocarpum, Stemonurus scorpioides and Tristania whittiana were representing characteristic of peat-swamp. There were two communities type namely Combretocarpus rotundatusShorea balangeran community and Palaquium leiocarpumEugenia densinervium community, where their sequence shows significantly related to both distances to river and peat-depth. The results suggested that the presence of habitat preference among tree species which almost all species tested were consistent significant to class of peatdepth.

\section{ACKNOWLEDGMENTS}

This work was financed by counterpart budget of Research Center for Biology under LIPI-JSPS Core University Program on Environmental Management of Wetland Ecosystems in Southeast Asia conducted under research program of "Valuation of peat-swamp forest in Central Kalimantan". I wish to thank Dr. Herwint Simbolon, Dirman, Wardi, and Aden Muhidin of Herbarium Bogoriense; Dr. Suwido H. Limin (Director of CIMTROP, Palangka Raya University (UNPAR), Palangka Raya) and his staffs Patih, Agung, and Adi; and anonymous for much help.

\section{REFERENCES}

Anderson JAR (1961) The ecological type of the peat swamp forest of Sarawak and Brunei in relation to their sylviculture [Ph.D. dissertation]. University of Edinburgh, Edinburg, Scotland.

Anderson JAR (1963) The flora of peat swamp forest of Sarawak and Brunei including a catalogue of all recorded species of flowering plants, ferns and fern allies. Gard Bull Sing 29: 131-228.

Anderson JAR (1964) The structure and development of the peat swamps of Sarawak and Brunei. J Trop Geogr 18: 7-16.
Anderson JAR (1972) Trees of Peat Swamp Forest of Sarawak. Forest Department of Sarawak, Kuching.

Anderson JAR (1983) The tropical peat swamps of Western Malesia. In: Gore AJP (ed) Ecosystem of the world, vol. 4B: mires: swamp, bog, fen and moor. Elsevier, Amsterdam.

Baillie IC, Ashton PS, Court MN, Anderson JAR, Fitzpatrick EA, Tinsley J (1987) Site characteristics and the distribution of tree species in Mixed Dipterocarp Forest on tertiary sediment in Central Sarawak, Malaysia. J Trop Ecol 3: 201-220

Becker P, Rabenold PE (1988) Water potential gradient for gaps and slope in a Panamanian tropical moist forest dry season. J Trop Ecol 4: 173184

Brady M (1997) Effects of vegetation changes on organic matter dynamics in three coastal peat deposit in Sumatra, Indonesia. In: Rieley JO, Page SE (eds) Biodiversity and sustainability of tropical peatland. Samara Publishing, Cardigan.

Graniero PA, Price JS (1999) The importance of topographic factors on the distribution of bog and heath in a Newfoundland blanket bog complex. Catena 36: 233-254.

Hurng WP, Lur HS, Liao CK, Kao CH (1994) Role of abcisic acid, ethylene and polymines in flooding-promoted senescence of tobacco leaves. J Plant Physiol 143: 102-105.

Hupp CR (1992) Riparian vegetation recovery pattern following stream channelization: a geomorphic perspective. Ecol 73: 1209-1226.

Ibrahim S (1997) Diversity of tree species in peat swamp forest in Peninsular Malaysia. In: Rieley JO, Page SE (eds) Tropical peatlands. Cardigan: Samara Publishing.

Inoue M, Nakagoshi N (2000) The effects of human impact on spatial structure of the riparian vegetation along the Ashida river, Japan. Landscape Urban Plan 53: 111-121.

Ismail MR, Noor KM (1996) Growth and physiological processes of young starfruit (Averhoa carambola L.) plants under soil flooding. Sci Hort 65: 229-238.

Jackson MB (1979) Rapid injury to peas by soil waterlogging. J Sci Food Agric 30: 143-152.

Mansur M (1999) Analisa vegetasi hutan rawa gambut di Bengkalis dan Kampar, Riau. Prosiding seminar hasil-hasil penelitian bidang ilmu hayat. Puslitbang Biologi-LIPI, Bogor.

Mirmanto E, Kartawinata K, Suriadarma A (1989) Mangrove and associated plant communities in the Barito River estuary and its vicinity, South Kalimantan. Ekol Indonesia 1: 42-54.

Mirmanto E (1999) Status hara daun dan serasah di hutan rawa gambut di Taman Nasional Tanjung Puting, Kalimantan Tengah. J Biol Indonesia 2: 267-275.

Miyamoto K, Suzuki E, Kohyama T, Seino T, Mirmanto E, Simbolon H (2003) Habitat differentiation among tree species with small-scale variation of humus depth and topography in a tropical heath forest of Central Kalimantan, Indonesia. J Trop Ecol 19: 43-54.

Naiola BP (1999) Water potential at turgor loss point of peat land forest plant species during flooding stress in Sebangau, Central Kalimantan (in Indonesian). Berita Biol 5: 341-348.

Newberry DM, Proctor J (1984) Ecological study in four contrasting lowland rain forest in Gunung Mulu National Park, Sarawak. J Ecol 72: 475-493.

Oliver CD, Larson BC (1990) Forest stand dynamics. McGraw-Hill, New York.

Page SE, Rieley JO, Shotyk ØW, Weiss D (1999) Interdependence of peat and vegetation in a tropical peat swamp forest. Philos Trans R Soc London [Biol] 354: 1885-1897.

Purwaningsih, Yusuf R (2000) Vegetation analysis of Suaq Balimbing peat swamp forest, Gunung Leuser National Park-South Aceh. Proceeding of the international symposium on tropical peatlands. Bogor, 22-23 November 1999.

Robertson PA, Weaver GT, Cavanaugh JA (1978) Vegetation and tree species patterns near the northern terminus of the southern floodplain forest. Ecol Monograph 48: 249-267.

Sambas EN, Susiarti S, Suhardjono (1994) Struktur dan komposisi hutan gambut di kabupaten Sanggau, Kalimantan Barat. Prosiding seminar hasil penelitian dan pengembangan sumberdaya hayati. Puslitbang Biologi-LIPI, Bogor.

Sambas EN, Suhardjono (1994) Struktur dan komposisi pohon hutan gambut primer dan sekunder di kabupaten Ketapang, Kalimantan Barat. Prosiding seminar hasil penelitian dan pengembangan sumberdaya hayati. Puslitbang Biologi-LIPI, Bogor.

Saribi AH, Riswan S (1997) Peat swamp forest in Nyaru Menteng Arboretum, Palangkaraya, Central Kalimantan, Indonesia: Its tree 
species diversity and secondary succession. Seminar on tropical ecology. Shiga, 21-22 June 1997.

Save R, Serrano L (1986) Some physiological and growth responses to kiwi fruit (Actinidia chinensis) to flooding. Physiol Plant 5: 301-309.

Schmidt FR, Ferguson JA (1957) Rain fall types based on wet and dry period ratios for Indonesia with New Guinea. Verhandelingen 42.

Shepherd PA, Rieley JO, Page SE (1997) The Relationship between forest vegetation and peat characteristics in the upper catchment of Sungai Sebangau, Central Kalimantan. In: Rieley JO, Page SE (eds) Tropical peatlands. Samara Publishing Limited, Cardigan.

Simbolon H, Mirmanto E (2000) The plants of peat swamp forest in Central Kalimantan, Indonesia. Proceeding of the International symposium on tropical peatlands. Bogor, 22-23 November 1999.

Siregar M, Sambas EN (2000) Floristic composition of management of Mensemat peat swamp Forest (MPSF) in Sambas, West Kalimantan.
Proceeding of the international symposium on tropical peatlands. Bogor, 22-23 November 1999.

Stoneman R (1997) Ecological studies in the Badas peat swamps, Brunei Darussalam. In: Rieley JO, Page SE (eds) Tropical peatlands. Samara Publishing Limited, Cardigan.

Suzuki E, Kohyama T, Simbolon H (1999) Vegetation of fresh water swampy areas in West and Central Kalimantan. Berita Biol 5: 273276.

Tang ZC, Kozlowski TT (1982) Some physiological and growth reponses of Betula papyrifera seedling to flooding. Physiol Plant 55: 415-420.

Yanoski TM (1982) Effects of flooding upon woody vegetation along parts the Potomac River flood plain. U.S. Geological Survey Professional Paper 1206. U.S. Geological Survey, Washington DC.

Yusuf R (1999) Analisis vegetasi dan degradasi jenis hutan rawa gambut bekas terbakar di Taman Nasional Tanjung Puting, Kalimantan Tengah. Berita Biol 5: 277-284. 